\title{
SEX DIFFERENCES IN LATE IRON AGE NORTHEAST ESTONIA AS INDICATED IN DENTAL PATHOLOGIES AND ENAMEL HYPOPLASIA
}

\author{
JANA Limbo \\ Institute of History, Tallinn University, Tallinn, Estonia
}

\begin{abstract}
Study of dental pathologies is important in investigating the health and diets of past populations. Dental pathologies of adult peoples show nutritional and hygienic habits in adulthood, but childhood metabolic stresses can be observed in the occurrence of linear enamel hypoplasia (LEH). Dental hard tissue pathologies (caries, pre mortem tooth loss, abscesses, calculus, reduction of alveolar bone, molar attrition) and LEH were observed over 15 years in individuals from Jouga cemetery $\left(11^{\text {th }}-16^{\text {th }} \mathrm{cc}\right.$. Northeast Estonia). The aim of the study was to trace sexual differences in diet and subsistence patterns through an analysis of dental pathology.
\end{abstract}

Keywords: linear enamel hypoplasia; dental pathologies; Late Iron Age

\section{INTRODUCTION}

Teeth are particularly resistant to decay because of their strong structure. They interact directly with environment, and they are susceptible to damage from physical and biological influences not operating on other skeletal elements [27]. In addition, teeth provide a wealth of information about, for example, diet, oral hygiene, stress, and subsistence economy [22]. Most of the dental diseases observed in archaeological skeletons arise as a result of the exposure of the teeth to foodstuffs and associated material taken into the mouth [18]. The mouth functions primarily as a food processor; the food type determines the microorganisms present in the mouth, and the condition of the person's teeth reflects the composition of the food that has come into contact with those teeth 
[22]. A considerable amount of work concerning dental diseases in ancient skeletons has focused on the investigation of ancient diets using diseases which originate from the attacks on the teeth from the substances in the oral environment. On the other hand, dental health is an important parameter contributing to the knowledge about the general health of people. Good teeth are a prerequisite for the individual's physical and psychological well-being. Good dental health means that the individual can consume all types of food, while poor health (e.g. caries or loose teeth) can be a result of monotonous, unbalanced diet, which in its turn can lead to an impaired general state of health [3]. There are differences between the populations in occurrences of dental pathologies depending on the type of food and the ways of its preparation. At the same time, intra-population differences may occur that depend on the sex or the status. However, it is not necessarily true that poor dental health reflects poor living conditions or vice versa. Anyway, dental pathologies - caries, pre mortem tooth loss, abscesses, dental calculus, reduction of alveolar bone, and attrition allow to describe the diet and subsistence patterns.

Dental caries is perhaps the most common of the dental diseases. Bacterial breakdown of carbohydrate food residues present in the mouth produces the acids responsible for caries cavities. Acidic by-products are not formed from the breakdown of non-carbohydrate food residues [18,25]. Fats, oils and meats (including fish) are noncariogenic. Major dietary carbohydrates are starches, found in large amounts, for example, in grain and potato. The most cariogenic carbohydrates are those of low molecular weight, such as sugars [18]. Caries is caused by a number of factors, and it is not possible to identify an individual factor as the most important. The composition of the food and the individual's eating habits are the factors that today are considered the most important [3].

Pre mortem tooth loss. Usually one cannot detect a distinct cause of tooth loss; however, it is certain that there have been cases of dental pathologies. Most common causes of pre mortem tooth loss are caries, alveolar reduction, and severe attrition $[3,5]$.

Chronic dental abscesses. An abscess may be defined as a collection of pus, surrounded by denser tissue, and within a cavity of the body. In skeletons it is possible to detect abscess cavities within the alveolus at the root apex. The abscesses may form in association with general periodontal infection, considerable dental attrition or caries $[6,11]$.

Dental calculus (tartar). Dental plaque on the tooth surface consists of microorganisms, which accumulate in the mouth. Plaque can become mineralised into dental calculus. It accumulates faster when there is sucrose in the diet 
[22]. Calculus develops most commonly on the teeth nearest to the salivary glands and appears to be a common finding on archaeological teeth [11,22].

Reduction of alveolar bone. The main cause of reduction in the marginal alveolar bone is periodontal disease [5]. Periodontal disease is an infection not only of alveolar bone but also of the soft tissues of the mouth. It starts as an inflammation of the gingivae, which may become chronic and finally periodontitis (inflammation of bone) may occur [11]. Resorption of bone and exposure of tooth roots develop [22]. A current suggestion is that a part of the cases of alveolar reduction only reflects the body's compensatory mechanism for extreme attrition [22].

Dental attrition. Dental attrition comes with ageing of the person and is not a dental disease. But severe attrition can predispose to other dental pathological conditions, e.g. caries and abscesses. A major factor affecting dental attrition is the processing of food. Attrition differences between groups also show differences in food consistency and nutritional habits [5]. Cultural factors also play an important role in dental attrition; however, they especially affect anterior teeth, and these factors can be eliminated to a certain degree if only molar attrition is compared.

The above stated dental pathologies enable the description of the dietary habits and lifestyle of adult individuals since about the $15^{\text {th }}$ year of age. But the episodes of childhood metabolic stresses of the same individuals may be described using the developmental defects of enamel called dental enamel hypoplasia.

Dental hypoplasia is any disturbance in tooth formation associated with macroscopic defects in the surface of enamel [21]. Furrow-type defects are most common and are often referred to as linear enamel hypoplasia (LEH) [10]. LEH is defined as horizontal lines of decreased enamel thickness on the external surface of the tooth crown. They are due to the disturbance of enamel formation during tooth crown formation in childhood. Such disturbances are caused by factors that affect the activity of ameloblasts so that the formation of dental enamel stops. After the child survives the stress, the normal formation of dental enamel continues, leaving a thinner line of enamel on the surface of the tooth. Such disturbances mainly result from systematic metabolic stress episodes caused by malnutrition or infectious diseases [8].

In Estonia, more detailed studies of dental pathologies have been made on Pada $\left(12^{\text {th }}-13^{\text {th }} c c\right)$, Tääksi $\left(14^{\text {th }}-18^{\text {th }}\right)$ and Pärnu St. John's Church $\left(17^{\text {th }}-18^{\text {th }}\right)$ population $[1,2,15,16]$. In all the three series, the frequencies of dental pathologies were very high, and there were no sexual differences in the occurrences 
of pathologies. The study of the bone material of Rebala Lastekangrud - stonechest graves from Bronze Age - showed very low occurrence of caries [12]. Data from Scandinavia and the Baltics were used for comparison.

In the current study, the most usual dental pathologies were examined among the Jõuga population from Northeast Estonia, $11^{\text {th }}-16^{\text {th }} \mathrm{cc}$. Sexual differences were found in the occurrence of these pathologies.

The differences in pathologic cases between men and women might suggest the variation of nutrition of the men compared to the women; the differences of hypoplasia frequencies may hint that boys and girls had different living conditions when young.

The aim was also to compare the results with the Pada $\left(12^{\text {th }}-13^{\text {th }} \mathrm{cc}\right.$. $)$ population. Pada cemetery is only $40 \mathrm{~km}$ away from Jõuga and was used at the same time as Jõuga cemetery. But if in Jõuga there were sand barrows, then in Pada there were underground pit graves.

It has been established that the women in Pada group had a smaller number of childhood metabolic stress occurrences than the men, and the dental pathologies spoke of a slight variance in their nutrition.

\section{MATERIAL AND METHODS}

Jõuga cemetery is situated in Northeast Estonia near the river of Rannapungerja, which flows into Lake Peipsi. Jõuga $\left(11^{\text {th }}-16^{\text {th }} \mathrm{cc}\right.$.) is the biggest Votic Grave cemetery in Estonia and consists of 260 sand barrows and several large graves of the so-called zhalnik type [14]. Jonuga cemetery was excavated by several archaeologists - O. Saadre in 1938, E. Ariste in 1949, H. Moora in 1950 and P. Ligi in 1980-1989. G. Sarap has made a detailed analysis of the dental discrete features of Jõuga skeletons [23]. She found that the inhabitants of Jõuga were of Northern Gracile odontological type like the Northeast Estonians today.

Statistically reliable sex determination can be made only in adult individuals, and therefore, the observations were made on individuals older than 15 years. There were 140 observable skulls (61 females and 79 males). A total of 1819 teeth were studied (779 in females and 1040 in males). All individuals were divided into five age groups. The age distribution showed that females had died at a younger age than males (Fig. 1). 


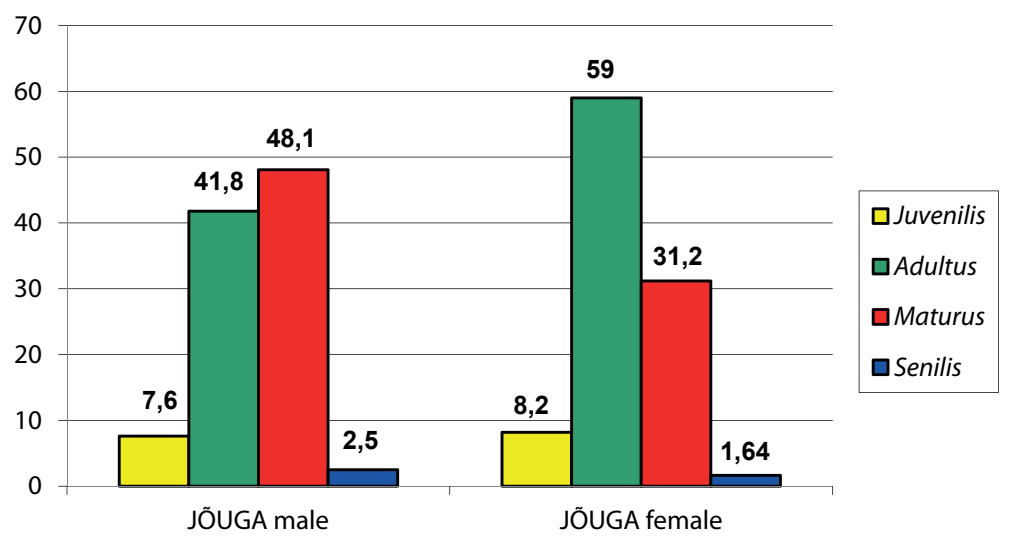

Figure 1. Age distribution of males and females in Jõuga cemetery

From dental hard tissue pathologies, the occurrences of caries, pre mortem tooth loss, abscesses, dental calculus, reduction of alveolar bone, degree of attrition of molars and occurrence of LEH were registered separately in females and males.

Dental caries. Occurrence of caries was registered in all observable teeth. Only those cavities that could be seen with the naked eye without the use of microscope or radiology were included [5]. The frequency of caries-affected individuals was calculated.

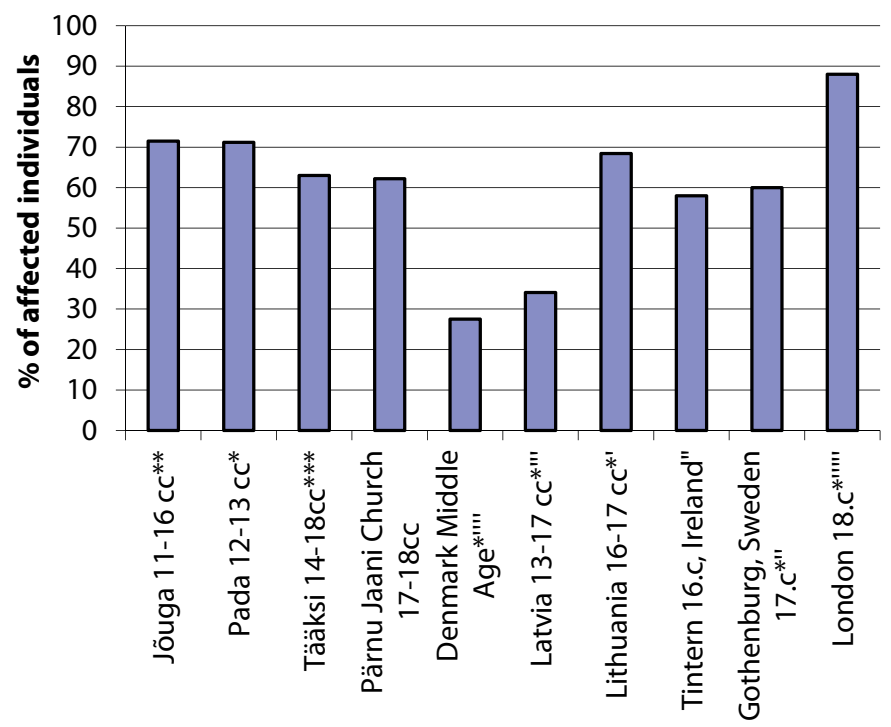

Figure. 2. Caries-affected individuals in various groups. 
Pre mortem tooth loss was registered when the alveolus of the tooth was closed.

Dental abscesses on the tips of the roots were registered. Only those abscesses that could be seen with the naked eye were included.

Dental calculus. The presence of calculus was registered in all teeth and the frequency of affected individuals was found.

Reduction of alveolar bone in the region of molars was registered according to Brothwell [6: 150]. An individual was considered to have a reduction of alveolar bone if the reduction degree was medium or considerable.

Attrition of molars was registered according to the criteria described by Bennike [5], with 6 degrees of attrition. Usually dental attrition is used for determining the age; this time, however, the purpose was to compare the attrition of the teeth in male and female individuals and to find possible variations in nutrition. As the number of older males in the group was bigger than the number of older females, dental attrition was registered in the adultus group were the distribution between men and women was equal.

Linear enamel hypoplasia (LEH) was registered for all permanent teeth. The frequency of affected individuals was found. To avoid differences due to bad preservation of the teeth, only the frequency of LEH in lower canines was used to compare males and females. Statistically significant differences between men and women were found using the $t$-test. The statistical package SPSS was used for data processing.

\section{RESULTS AND DISCUSSION}

The occurrence of several dental diseases in archaeological skeleton series is known to increase with age $[3,5,15]$. As women had died at earlier ages than men, the occurrence of pathologies in females might be underestimated.

Dental caries. $69.2 \%$ of observed women and $73.8 \%$ of observed men had caries (Table 1). This rate is very high, only the modern so-called civilized human populations have a higher percentage of caries - more than $90 \%$ may be infected. Generally, the percentage of caries has increased step-by-step with time $[4,6,7]$; in Jõuga group, however, the percentage of caries is much higher than in Late Middle Age skeleton series in Estonia $[2,1]$. Similar percentage of caries was established for the Pada skeleton series, the latter being also located in Northeast Estonia and dating from the same period. 
Table 1. Occurrences of dental pathologies in males and females.

\begin{tabular}{|c|c|c|c|c|c|c|c|}
\hline & \multicolumn{3}{|c|}{ Males } & \multicolumn{3}{|c|}{ Females } & \multirow{2}{*}{$\begin{array}{c}\text { Differences between } \\
\text { males and females } \\
\text { t-test; value of } p\end{array}$} \\
\hline & $\mathbf{N}$ & $\mathrm{n}$ & $\%$ & $\mathbf{N}$ & $\mathbf{n}$ & $\%$ & \\
\hline Caries & 61 & 45 & 73.8 & 52 & 36 & 69.2 & 0.59 \\
\hline Pre mortem tooth loss & 70 & 39 & 55.7 & 58 & 29 & 50 & 0.52 \\
\hline Abscesses & 61 & 9 & 14.6 & 51 & 9 & 17.6 & 0.68 \\
\hline Calculus & 29 & 22 & 75.8 & 27 & 16 & 59.3 & 0.19 \\
\hline Reduction of alveolar bone & 70 & 32 & 45.7 & 56 & 22 & 39.3 & 0.69 \\
\hline
\end{tabular}

The women of Jõuga were somewhat less infected by caries than the men. The difference was statistically insignificant (Table 1). Supposedly, the men and the women had very similar dietary habits, eating mainly food rich in starches. This cariogenic food consisted, for example, of food made from flour. Dried berries and honey are also high in sugar. It is probable that they ate comparatively little meat and fish.

The later skeleton series of Tääksi village burial ground from the $14^{\text {th }}$ $18^{\text {th }} \mathrm{cc}$ and the burial ground of Pärnu St John's Church from the $17^{\text {th }}-18^{\text {th }}$ $\mathrm{cc}$ showed less caries, but again, there were no differences between men and women. At the same time, in Lund (Sweden), men were more infected by caries than women from the $10^{\text {th }}$ to the $16^{\text {th }}$ century [3]. The study conducted in the present-day United States among various ethnic groups showed that women had caries more often than men. These differences have been explained by behavioural habits rather than physiological differences $[17,26]$.

Caries was mostly found in the tooth neck (Table 2). In modern Western populations, caries is most frequent in occlusal fissures and interstitial contact areas and reaches its maximum incidence in early adult life [19].

Table 2. Occurrence and location of caries in men's and women's teeth.

\begin{tabular}{c|c|cc|cc|cc}
\hline \multirow{2}{*}{$\begin{array}{c}\text { Observed } \\
\text { teeth }\end{array}$} & \multicolumn{2}{|c|}{ Teeth with caries } & \multicolumn{2}{c|}{$\begin{array}{c}\text { Caries primarily } \\
\text { on neck }\end{array}$} & \multicolumn{2}{c}{$\begin{array}{c}\text { Caries primarily } \\
\text { on crown }\end{array}$} \\
\cline { 2 - 9 } & $\mathbf{N}$ & $\mathbf{n}$ & $\%$ & $\mathbf{n}$ & $\%$ & $\mathbf{n}$ & $\%$ \\
\hline Men & 821 & 85 & 10.3 & 63 & 74.1 & 12 & 14.1 \\
\hline Women & 622 & 62 & 10.0 & 41 & 66.1 & 9 & 14.5 \\
\hline
\end{tabular}

In the Middle Ages and earlier populations, caries is mainly found at the buccal side of the tooth neck, and the percentage of findings increases with age. Caries can develop on the tooth neck only if the latter has been exposed due to 
alveolar bone reduction, which, in its turn, is caused by infectious processes in the gums and dental attrition. Both of these pathologies increase with the age. Highly abrasive food that wears dental surfaces and prevents caries on the occlusive surface is the cause of most cases of caries developing on the tooth neck.

There were no differences between the Jõuga men and women, so one may deduce that the composition and processing methods (abrasiveness and the percentage of starches) of food were similar for both men and women.

Pre mortem tooth loss. The occurrence of tooth loss before death was also similar in men and women $(\hat{O}=55.7 \%$; $q=50.0 \%)$. The rate of occurrence is extremely high; more than half of the grown individuals had either removed teeth or teeth that had fallen out due to far-developed dental pathologies. It is probable that caries was the reason of tooth loss in Jonuga group because caries was very frequent in Jõuga individuals, while they had comparatively rare cases of alveolar bone reduction, which is the second important cause of pre mortem tooth loss. Similar high occurrence of pre mortem tooth loss was noticed in $12^{\text {th }}-13^{\text {th }} \mathrm{cc}$ Northeast Pada population and $14^{\text {th }}-15^{\text {th }} \mathrm{cc}$ Lund population (Sweden) $[3,15]$. These populations did not have specific differences between men and women either.

Abscesses. The occurrence of abscesses was low, and although women had somewhat more abscesses than men $(\hat{\partial}=14.6 \% ; \varnothing=17.6 \%)$, the difference was statistically insignificant. Abscess frequencies vary considerably in different populations, and the pathology is more genetically predisposed than other dental pathologies. As abscesses develop in response to other severe dental pathologies, mainly caries and periodontosis, one may say that neither men nor women had severe, far-developed dental pathologies. Maybe one of the reasons for infrequent pathologies was the short lifespan, as only three individuals in the group were older than 55 years.

Calculus. Men had calculus more often than women $(\hat{\delta}=75.8 \%$; $q=59.3 \%)$, but the difference was statistically insignificant. The occurrence of calculus is correlated with the amount of carbohydrates in the food and with the amount of food that sticks to the teeth. If the food is more processed and richer in carbohydrates, it causes more calculus. The composition of saliva and oral hygiene also play an important role here. As the general percentage of occurrence of caries and its distribution on various locations of teeth did not vary in men and women, one can say that the chemical and physical characteristics of food were the same both for men and women. Maybe the preparation of food dif- 
fered somewhat between men and women. On the other hand, the variance of calculus may be considered incidental, being caused by too small sample size. There were fewer findings of calculus among the Pada series from the same period where men had calculus more frequently than women. Among the later skeletal series (Tääksi village burial ground from the 14 th- $18^{\text {th }} \mathrm{cc}$ and Pärnu St John's Church burial ground from the $17^{\text {th }}-18^{\text {th }} \mathrm{cc}$ ), calculus was significantly more frequent and occurred more often in men than in women $[2,1]$.

Reduction of alveolar bone. Men had reduction of alveolar bone more often than women $(\hat{\delta}=45.7 \%$; $+=39.3 \%)$, and the difference was statistically insignificant. The main reason of degenerative changes of alveolar bone is periodontal disease, and periodontal disease often develops when calculus accumulates between the tooth and the soft tissue. Besides alveolar bone degeneration, teeth roots are also exposed in association with dental attrition, so older individuals have reduction much more often. In Jõuga group, calculus was more frequent in men. The number of older men was significantly higher than of women. This may also contribute to alveolar bone reduction being more prevalent in men. In Pada group, the men had also higher occurrence of reduction. The Estonian skeleton series of later periods showed more frequent alveolar bone reduction in women [1].

Dental attrition. Attrition of molars in the adultus age class was slightly higher in males, except for lower second molars. The differences were statistically insignificant (Table 3). Dental attrition is the natural result of masticatory stress upon dentition, and it usually occurs on the biting or occlusal surfaces of the teeth during grinding of the crowns of the teeth against each other. Attrition is not a dental disease but can predispose to other dental pathologies, e.g. caries and abscesses. The major factor affecting dental attrition is the processing of foods [10]. The more processed the food is before eating, the less it wears the teeth. At the same time, dental attrition is useful in some sense, as it clears the dental surfaces of food particles. In Danish medieval and Viking period samples, males had a somewhat higher degree of attrition as well. It was the same in Pada. In Jõuga series, there was no significant difference in molar attrition between men and women. As men and women were also equal in the cases of primary tooth neck caries, one can propose that there were no differences in the physical characteristics of the food (primarily in processing) between men and women. 
Table 3. Degree of attrition of molars in males and females.

\begin{tabular}{ccccccc}
\hline & upperM1 & upperM2 & upperM3 & lowerM1 & lowerM2 & lowerM3 \\
\hline $\boldsymbol{t}$ & 1.02 & 0.74 & 0.9 & 2.48 & -0.03 & 0.52 \\
\hline $\boldsymbol{p}$ & 0.31 & 0.47 & 0.37 & 0.31 & 0.97 & 0.6 \\
\hline Males & & & & & & \\
\hline average & 3.7 & 2.8 & 1.9 & 3.85 & 2.9 & 2.2 \\
\hline STD & 0.64 & 0.68 & 0.61 & 0.72 & 0.7 & 0.75 \\
\hline Females & & & & & & \\
\hline average & 3.5 & 2.65 & 1.7 & 3.4 & 2.9 & 2.1 \\
\hline STD & 0.73 & 0.77 & 0.62 & 0.5 & 0.8 & 0.85 \\
\hline
\end{tabular}

Linear enamel hypoplasia (LEH). The average expression of hypoplasia was $74.1 \%$ of the individuals $(\hat{O}=68.9 \%, q=80 \%)$. In order to avoid mistakes in comparing the childhood stress levels of men and women due to the different existing teeth, the existence of hypoplasia was compared only on lower canines, the canines being the most hypoplastic. The sex-related differences in LEH prevalence were very small (Table 4 ).

Table 4. Linear enamel hypoplasia (LEH) in men and women.

\begin{tabular}{l|ccc|ccc|c}
\hline & \multicolumn{3}{|c|}{ Males } & \multicolumn{3}{c|}{ Females } & \multirow{2}{*}{$\begin{array}{c}\text { Differences between } \\
\text { males and females, } \\
\text { t-test; value of } \boldsymbol{p}\end{array}$} \\
\cline { 2 - 7 } & $\mathbf{N}$ & $\mathbf{n}$ & $\%$ & $\mathbf{N}$ & $\mathbf{n}$ & $\%$ & 0.25 \\
\hline LEH in all teeth & 45 & 31 & 68.9 & 40 & 32 & 80.0 & 0.71 \\
\hline LEH in lower canines & 28 & 20 & 71.4 & 25 & 19 & 76.0 & 0 \\
\hline
\end{tabular}

In modern populations, the incidence of hypoplasia usually remains under 20 percent [13], but in historical skeleton series, LEH occurs more often. In early modern samples in Europe, the frequencies of hypoplasia reach 100\% [20]. The skeleton series studies in Pärnu, Estonia, from the $17^{\text {th }}-18^{\text {th }}$ cc indicated $88 \%$ hypoplasia with no sex-related differences. Among Pada (Northeast Estonia 12.-13. cc) skeletons, the LEH percentage was 77.8, while women suffered from it considerably less frequently than men. Differences between men and women in occurrences of LEH may be a consequence of genetic difference (males are more sensitive to stress than females) or a consequence of cultural differences, boys or girls are better protected culturally from stress [9, 20, 24]. LEH was slightly more frequent in women; however, the difference is too small and suggests that boys and girls were raised in similar living conditions. 


\section{CONCLUSIONS}

In Jõuga group, both men and women showed high frequency rate of all dental pathologies. The factors contributing to the high rate of dental illnesses were probably poor dental hygiene, food consisting extensively of carbohydrates (e.g., cereals), microorganisms present in the oral cavity causing pathologies and perhaps also individual inclination for infections.

Although the frequency of all dental pathologies evidenced was slightly higher among men, there were no statistically significant sex-related differences. The age progressive factor of dental pathologies is suggested as the reason for the more frequent occurrence of dental pathologies in men over women. According to the frequency of dental pathologies in men versus women, the dietary habits of adult individuals (the composition, preparation and consumption of food) can be deduced to be similar in men and women. The hypoplasia caused by childhood metabolic stress was more frequent in Jõuga women than in men, although the variance was of no statistical significance. As men are more sensitive to stress, one can presume that the boys of Jonuga population experienced less stress than the girls. In the Pada skeleton series from the same period, there was no sex-related dietary difference between adult men and women on the basis of dental pathologies, but there were more LEH occurrences among men than among women. Thus, the living conditions of the boys and girls of these two populations, dating from the same period and being in close locations but being culturally different, could have varied.

\section{REFERENCES}

1. Allmäe R., Limbo J. (2008). 16.-18. sajandi Pärnu garnisoni kalmistutele maetute anntropoloogiast. In: Pärnumaa 1. köide. Loodus. Aeg. Inimene. Tallinn: Eesti Entsüklopeediakirjastus, 369-387.

2. Allmäe R. (1999). Dental and cranial pathologies in Tääksi $14^{\text {th }}-18^{\text {th }} \mathrm{cc}$. skeletal population. Papers on Anthropology, 8, 9-14.

3. Arcini C. (1999). Health and disease in Early Lund: osteopathologic studies of 3305 individuals buried in the first cemetery area of Lund 990-1536. Department of Community Health Sciences, Medical Faculty, Lund University, Sweden.

4. Balčiūnienè I. (1987). Odontologija drevnego i sovremennogo naselenija Litvy. Avtoreferat dissertacii na soiskanie učenoj stepeni doktora biologičeskih nauk. Vilnius = Бальчюнене И. А. Одонтология древнего и современного населения Литвы. Автореферат диссертации на соискание ученой степени доктора биологических наук. Вильнюс. (Manuscript at Vilnius University Library). 
5. Bennike P. (1985). Paleopathology of Danish Skeletons. Copenhagen: Akademisk Forlag.

6. Brothwell D.R. (1972). Digging up bones. London: Trustees of the British Museum.

7. Derums V. (1970). Sostajanie zdorov'ja nasilenija i vračevanija v drevnej Pribaltike. Riga = Дерумс В. Я. Состаяние здоровья насиления и врачевания в древней Прибалтике. Рига.

8. Goodman A.H., Rose J.C. (1991). Dental enamel hypoplasias as indicators of nutritional status. In: M.A. Kelley and C. S. Larsen (Eds.) Advances in Dental Anthropology. Pp. 279-293. New York: Wiley-Liss.

9. Goodman A.H., Armelagos G.J. (1985). Factors Affecting the Distribution of Enamel Hypoplasias within the Human Permanent Dentition. Am Journal of Phys Anthropology, 68, 479-493. https://doi.org/10.1002/ajpa.1330680404

10. Hillson S. (1996). Dental anthropology. Cambridge University Press.

11. Hillson S. (2005). Teeth. Cambridge University Press.

12. Kalman J. (1999). Human remains from the stone-cist graves of Rebala Lastekangrud, North Estonia. Eesti Arheoloogiaajakiri, 3, 1, 19-34.

13. Krenz-Niedbała M. (2001) Biological and cultural consequences of the transition to agriculture in human populations on Polish Territories. Summary of the thesis. Variability and evolution, 9, 89-99.

14. Ligi P. (1993). Vadjapärased kalmed Kirde-Eestis (9.-16. sajand). (MT. 2.) Votic Graves in North-East Estonia ( $9^{\text {th }}-6^{\text {th }}$ centuries AD). (MT. 2.), Tallinn, 7-175.

15. Limbo J. (2004). Pada kalmistu indiviididel esinevad hambapatoloogiad (XIIXIII saj.). Denthal pathologies in individuals from Pada cemetery $\left(12^{\text {th }}-13^{\text {th }}\right.$ centuries). Eesti Arholoogiaajakiri, 8, 1, 49-75.

16. Limbo J. (2006). Dental enamel hypoplasia in the Pada Cemetery $\left(12^{\text {th }}-13^{\text {th }} \mathrm{cc}\right.$. population in Northeast Estonia. Papers on Anthropology, 15, 114-123.

17. Lukacs J.R., Largaespada L.L. (2006). Explaining Sex Differences in Dental Caries Prevalence: Saliva, Hormones, and "Life-History" Etiologies. Am Journal of Human Biology, 18, 540-555. https://doi.org/10.1002/ajhb.20530

18. Mays S. (2006). The archaeology of human bones. London and New York: Routledge.

19. Moore W.J., Corbett E. (1973). The distribution of Dental caries in Ancient British Populations. II. Iron Age, Romano-British and Mediaeval Periods. Caries Res, 7, 139-153. https://doi.org/10.1159/000259838

20. Palubekaite Ž., Jankauskas R., Boldsen J. (2002). Enamel Hypoplasia in Danish and Lithuanian Late Medieval/Early Modern Samples: A Possible Reflection of Child Morbidity and Mortality Patterns. Int J Osteoarchaeol, 12, 189-201. https://doi.org/10.1002/oa.607

21. Pindborg J.J. (1970). Pathology of the Dental Hard Tissues. Munsgaard. Copenhagen. 
22. Roberts C., Manchester K. (1995). The Archaeology of Disease. Cornell: Cornell University Press.

23. Sarap G. (1993). Jõuga kalmistu odontoloogiline iseloomustus. In: Vadjapärased kalmed Eestis 9.-16. sajandil. Tallinn, 249-256.

24. Šlaus M. (2000). Biocultural Analysis of Sex Differences in Mortality Profiles and Stress Levels in the Late Medieval Population from Nova Rača, Croatia. Am J Physical Anthropol, 111, 2, 193-210. https://doi.org/10.1002/ (SICI)1096-8644(200002)111:2\%3C193::AID-AJPA6\%3E3.0.CO;2-0

25. Touger- Decker R., van Loveren C. (2003). Sugars and dental caries. Am J Clin Nutr, 78, 4, 881S-892S. https://doi.org/10.1093/ajcn/78.4.881S

26. Walker P.L. (1988). Sex Differences in the Diet and Dental Health of Prehistoric and Modern Hunter-Gatherers. In: Proceedings of the VI European Meeting of the Paleopathology Association, Universidad Complutense de Madrid, 249-260.

27. White T. (2000). Human Osteology. San Diego, California. USA: Academic Press.

\section{Address for correspondence:}

Jana Limbo-Simovart

E-mail: jana.limbo@gmail.com 